\title{
Socioeconomic modifications of the universal soil loss equation
}

\author{
A. Erol ${ }^{1}$, Ö. Koşkan ${ }^{2}$, and M. A. Başaran ${ }^{3}$ \\ ${ }^{1}$ SDÜ Faculty of Forestry, Department of Watershed Management, Isparta, Turkey \\ ${ }^{2}$ SDÜ Agricultural Faculty, Department of Biometric Genetics, Isparta, Turkey \\ ${ }^{3}$ Western Mediterranean Forestry Research Institute, Antalya, Turkey \\ Correspondence to: A. Erol (aytenerol@sdu.edu.tr) \\ Received: 28 April 2015 - Published in Solid Earth Discuss.: 15 June 2015 \\ Revised: 16 August 2015 - Accepted: 18 August 2015 - Published: 28 August 2015
}

\begin{abstract}
While social scientists have long focused on socioeconomic and demographic factors, physical modelers typically study soil loss using physical factors. In the current environment, it is becoming increasingly important to consider both approaches simultaneously for the conservation of soil and water, and the improvement of land use conditions. This study uses physical and socioeconomic factors to find a coefficient that evaluates the combination of these factors. It aims to determine the effect of socioeconomic factors on soil loss and, in turn, to modify the universal soil loss equation (USLE). The methodology employed in this study specifies that soil loss can be calculated and predicted by comparing the degree of soil loss in watersheds, with and without human influence, given the same overall conditions. A coefficient for socioeconomic factors, therefore, has been determined based on adjoining watersheds (WS I and II), employing simulation methods. Combinations of $C$ and $P$ factors were used in the USLE to find the impact of their contributions to soil loss. The results revealed that these combinations provided good estimation of soil loss amounts for the second watershed, i.e., WS II, from the adjoining watersheds studied in this work. This study shows that a coefficient of 0.008 modified the USLE to reflect the socioeconomic factors, such as settlement, influencing the amount of soil loss in the studied watersheds.
\end{abstract}

\section{Introduction}

Soil erosion is a natural process for landscape development, although denudation processes are accelerated by human impact. Moreover, it determines the landscape and the landforms, the soil and water quality, the vegetation recovery and the fate of societies (Zhao et al., 2013). This phenomenon is a global environmental threat that reduces the productivity of all natural ecosystems (Kertész, 2009; Pimentel and Burgess, 2013; Leh et al., 2013), including soil where the adaptation capacity is weak (Cerdà, 2000; Leh et al., 2013). Pimentel (1993) numerically stated that between 30 and $50 \%$ of the world's arable land is significantly degraded by soil erosion. Additionally, erosion-induced soil quality deterioration is prevalent all over the world (Harden, 2001; Zhao et al., 2013), obstructing the global food source and socioeconomic security. According to Lal (2015), soil degradation trends can be reversed by conversion to a restorative land use and adoption of recommended management practices. Protection and restoration of land uses on slopes are essential to minimize soil erosion, which will not only contribute to greater safety (Giménez Morera et al., 2010; Wildemeersch et al., 2015; Mekonnen et al., 2014; Yazdani et al., 2015) in many land uses around the world but will also help sustain soil and water quality and quantity of water in watershed areas. There is a need to research different aspects of the soil and land degradation that affect the fate of the Earth system (Keesstra et al., 2012; Mandal and Sharda, 2013; Zhao et al., 2013; Ganjegunte et al., 2014; Mukhopadhyay and Maiti, 2014; Brevik et al., 2015). In watershed areas it is necessary to develop efficient new approaches to conserve soil and water resources due to increased soil loss by human activities as a consequence of population growth. Thus, new approaches are also very vital to prevent soil erosion in support of food and energy security.

Soil loss can trigger land degradation that can result in loss of the services that soil offers to human societies. Many experiments have shown that the impacts of soil loss on ecosystem functions have direct physical impacts on human soci- 
eties (Cardinale et al., 2012; Berendse et al., 2015; Brevik et al., 2015; Yazdani et al., 2015). Thus, the prevention of soil erosion in support of food and energy security is a significant issue for mankind. Young (1993) indicated that the challenges of soil erosion are more severe in the heavily populated, under-developed, and ecologically fragile areas of the world. Lal (1981) and Eswaran et al. (2001) asserted that misuse of soils, resulting from a desperate attempt by farmers to increase production for the growing population, aggravates soil quality degradation. Tesfahunegn (2013) further claims that severity of such degradation is higher in developing countries, where the economy mainly depends on agriculture.

Soil erosion, which is one of the primary issues that forestry and agriculture agencies have to deal with, is a critical problem in Turkey. The current population of Turkey is 76.7 million (TUIK, 2014), and the land surface area is 78 million ha; this comprises $36 \%$ of agricultural land, $27.6 \%$ of rangeland, and $29.8 \%$ of forest and shrub cover, with the remaining $6.5 \%$ of land accounting for settlements and water bodies (OSIB, 2005). To put it bluntly, it is anticipated that there will be a dramatic increase in settlements due to rapid population growth, resulting in intensive construction in the mountainous areas, which are especially used for agriculture and forest. Indeed, soil erosion is a key issue in mountainous regions worldwide (Leh et al., 2013; Mandal and Sharda, 2013; Haregeweyn et al., 2013; Wang and Shao, 2013). Mountain soils develop in very sensitive environments subject to natural and anthropic disturbances (e.g., Cerdà and Lasanta, 2005; Vanwalleghem et al., 2011; Van der Waal et al., 2012; García Orenes et al., 2012), and they are often located at the interface with densely settled areas, which may be considerably affected by sediment release from upstream erosion (Ziadat and Taimeh, 2013; Cao et al., 2014; Lieskovský and Kenderessy, 2014). Similarly, watersheds of Turkey are located in mountainous areas, and these areas, which are mainly under the effect of soil erosion, impact water quality and quantity. Furthermore, land use management practices are becoming increasingly important due to growth in improper land use in the country and existing considerable spatial heterogeneity in terms of land use and management, topography, and socioeconomic conditions all over Turkey.

Land degradation and especially soil erosion have been studied over long time periods for physical processes such as geography, geology, agronomy, and engineering using the universal soil loss equation (USLE; Boardman et al., 2013). The USLE proceeds to be the most widely used model for soil loss estimations. Several studies have been performed in India (Ali and Sharda, 2005; Sharda and Ali, 2008; Narain et al., 1994) and other countries (Van Rompaey and Govers, 2002; Larson et al.,1997) to estimate the performance of the USLE in predicting soil loss under different situations (Mandal and Sharda, 2013). Furthermore, in the eastern Himalayan region potential soil erosion rates for different states of the region were estimated by collecting data on various parameters of the USLE by Mandal and Sharda (2013).

However, Castro et al. (2001) criticized that the USLE has limited applications. In the present study we tried to find a coefficient to modify the USLE, instead of the RUSLE, which is a better and revised version of the USLE. The main reason is that data from previous studies were obtained from the USLE, which is the most commonly used model in Turkey. It is obvious that the use of the RUSLE would be more perfect to achieve better results when in a similar study designed using actual data.

Jayarathne et al. (2010) established that there is a strong positive relationship between land degradation and soil erosion, as well as land degradation and population density. Strong negative relationships were also observed between land degradation and the land/man ratio. Boardman et al. (2003) stated the physical and socioeconomic factors drive soil erosion; therefore, these factors need to be addressed in tandem. However, it is often the case that the studies on this subject are not undertaken in an interdisciplinary fashion (Boardman et al., 2003). Given this view, evaluating physical factors with socioeconomic factors is the best starting point for determining the degree of soil loss using two different disciplines. Additionally, Evans (1996) made an attempt with his assessment of the socioeconomic and physical drivers, impacts and costs of erosion for the UK. On the other hand, few studies have evaluated both physical and socioeconomic factors, using the effects of settlements in the USLE method. However, Veldkamp and Lambin (2001) states that the incorporation of socioeconomic drivers of land use change is critical for the accurate representation of land use change. Furthermore, as pointed out by Verburg et al. (2004), the integration of social, political, policy and economic factors into land use change modeling is often not successful because of difficulties in quantifying socioeconomic factors and integrating such data with other environmental data (Leh, 2011).

Furthermore, the need for an integrated land and water management policy with the new approaches to face erosion problems in watersheds of arid and semiarid regions is universally accepted (Haregeweyn et al., 2006; Vanmaercke et al., 2011; Grimaldi et al., 2013; Galdino et al., 2015); therefore, the development of a new approach to assess the soil loss in those watersheds can be an interesting experience.

In the present study, socioeconomic factors were spatially considered as settlements including humans and animal shelters. Thus, cropping management ( $C$ factor) and erosion control practice ( $P$ factor) were used to estimate the contribution of socioeconomic factors in the USLE (Wischmeier and Smith, 1962, 1965, 1978; Lal, 1994). In addition, a calculation method was suggested to determine a coefficient that would consider the interactions of physical and socioeconomic factors using a simulation method. The amount of soil loss resulting from human and animal influence in settlements was calculated using simple mathematical equations. 


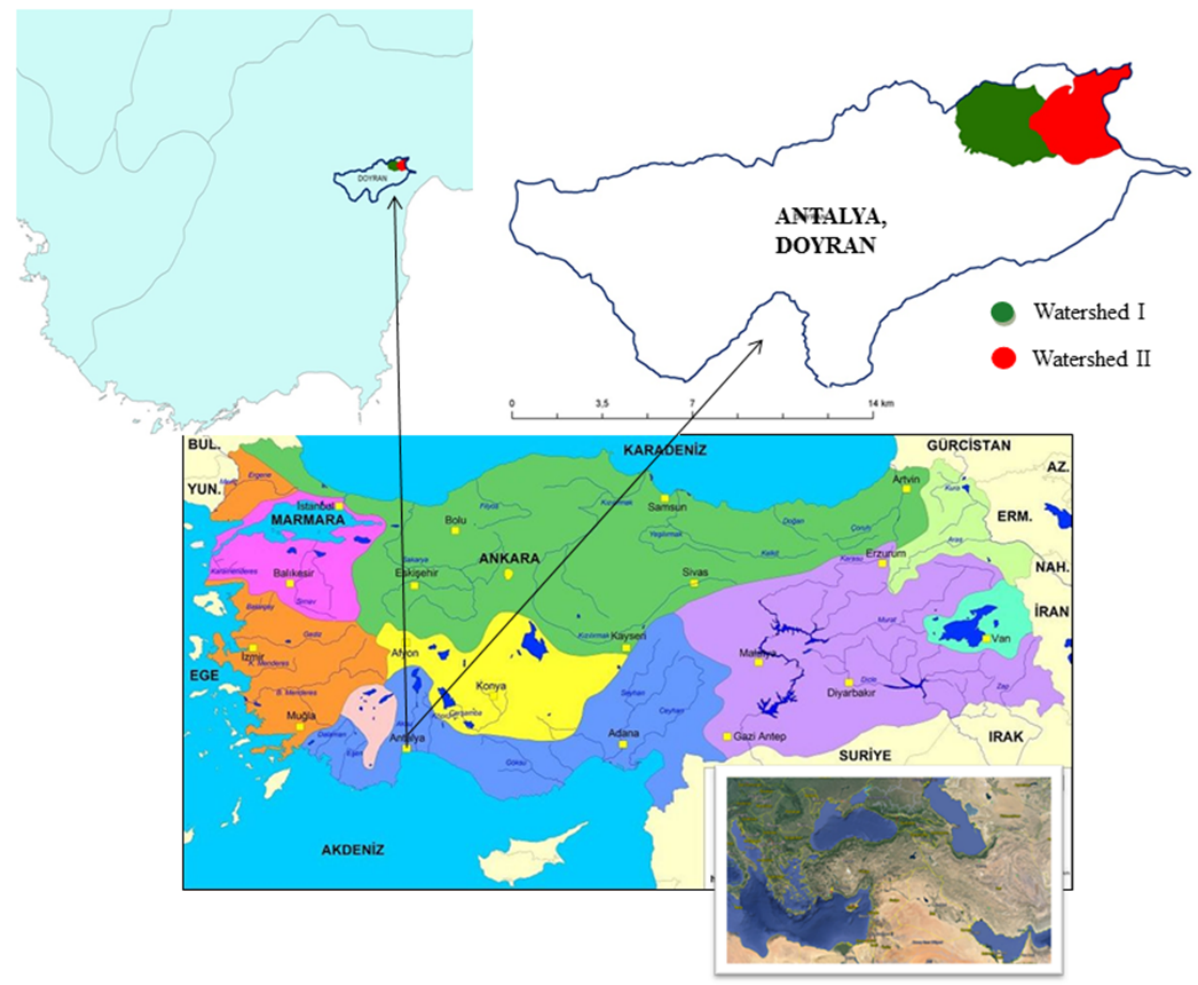

Figure 1. Location of the study area in Antalya, Turkey.

Using this method, a coefficient that could distinguish between settlements, which consist of both humans and animals, and physical factors affecting erosion was incorporated into the USLE for two small watersheds with similar characteristics.

In this study, we hypothesized the presence of settlements in the study area, where the impact on erosion in the USLE depended on the number of people and animals due to their settlements. The main objective is to determine the amount of erosion arising from these factors and, thus, to ascertain the contribution of these factors within the USLE.

\section{Materials and methods}

\section{Description of the study area}

Two small adjoining watersheds $\left(36^{\circ} 54.074^{\prime} \mathrm{N}\right.$, $\left.30^{\circ} 31.536^{\prime} \mathrm{E}\right)$ covering areas of 700 and 800 ha, respectively, located in a small Mediterranean watershed in Antalya, western Turkey (Fig. 1), were selected as the study areas. Thus, these watersheds with similar properties allow comparison with each other (Özhan, 2004). Hereafter, the watersheds are referred to as WS I and WS II; some of their features are described in Table 1. Additionally, open forest was a forest area not characterized by productive forest cover, due to destruction. Therefore, these forest areas were considered as dense and open forests in two adjoining watersheds.
Land uses of WS I are dense forest, open forest and lake constituting $630.4,60.4$, and 9.2 ha, which comprise of $\approx 90$ and 51,9 and $1 \%$ of the total area, respectively. The total area of WS I is encompassed forest trees and other vegetation types. The cover layer of WS I (i.e., $700 \mathrm{ha}$ ) is $68 \%$ (Table 1).

WS II includes dense forest (408 ha), open forest ( $8 \mathrm{ha}$ ), lake ( 2 ha), orchard (255 ha), agriculture (68 ha), settlement (11 ha), and greenhouse (48 ha), which consist of 51, 1, 0.25, $31.88,8.5,1.38$, and $6 \%$ of the total area in the watershed, respectively. The cover layer in the watershed is $40 \%$, and the total area of the watershed ( $800 \mathrm{ha}$ ) encompasses forest trees and various types of vegetation. Altitudes of the watersheds are 664 and $316 \mathrm{~m}$, respectively. Soil group and texture of the watersheds are red Mediterranean soil and clay loam (Table 1).

\section{Data from GIS, previous studies and use in the USLE}

The USLE is used in Turkey as the most common mathematical model for predicting the amounts of soil loss in forests and rangelands. Previously, Turkey has been studied primarily with reference to the $R, C$, and $P$ factors in the model (Doğan and Güçer, 1976; Çanga, 2006).

The topographic features - such as $L, S$, evaluation, and aspect - and land use data of the present study were obtained using GIS; other data - such as soil group and factors in the USLE, which were used to determine a coefficient 
Table 1. Selected features of *WS I and WS II obtained from GIS and previous studies; soil erodibility factor $(K)$ in terms of soil group; some data from GIS and previous studies* of WS I and WS II. Red Mediterranean soils $(T)$; slope length factor $(l)$; and slope steepness factor $(s)$.

\begin{tabular}{lll}
\hline Study area features & WS I & WS II \\
\hline Location & Antalya center & Antalya center \\
Area (ha) & 700 ha & 800 ha \\
Annual precipitation $(\mathrm{mm})$ & $1076.7 \mathrm{~mm}$ & $1076.7 \mathrm{~mm}$ \\
Altitude & 664 & 316 \\
Vegetation cover $(\%)$ & 68 (except lake) & 40 (except lake) \\
*Soil group $^{*}$ Texture & Red Mediterranean soils $(T)$ & Red Mediterranean soils $(T)$ \\
Human impact & Clay loam & Clay loam \\
${ }^{*} K$ factor & Almost no human impact & Human impact \\
$(0-15$ cm) & & \\
Total area (ha) & 0.12 & 0.12 \\
Dense forest (ha) & 700 & 800 \\
Open forest (ha) & 630.4 & 408 \\
Lake (ha) & 60.4 & 8 \\
Orchard (ha) & 9.2 & 2 \\
Agriculture (ha) & - & 255 \\
Settlements (ha) & - & 68 \\
Greenhouse (ha) & - & 11 \\
Aspect & - & 48 \\
Length & Southeast & Southeast \\
22.1 & 4100 & 3765 \\
$185.5204^{0.5}$ & & 22.1 \\
S (\%) & & $170.362^{0.5}$ \\
Max. length & 27.63 & 14.82 \\
Min. length & 1230 & 1230 \\
Difference $L$ & 97 & 37 \\
$l$ (m) & 1133 & 558 \\
\hline & 13.62 & 13.05 \\
\hline & &
\end{tabular}

in the USLE - were obtained from previous studies (Doğan and Güçer, 1976; Arnoldus, 1977; Balc1, 1996; Cebel et al., 2013). Figure 2 shows the working steps of factors in the USLE to determine soil loss with the USLE integrated in GIS (Fistikogli and Harmancioglu 2002). Parameters before the step digital elevation model (DEM) such as land covers and after the step D.E.M such as aspects, slopes, and the $L S$ factor were mathematically calculated by GIS to determine the amount of soil loss for the watersheds.

In addition, precipitation amounts were obtained from a single station, which was close to the two watersheds (Table 1). The reason is that there are no sufficient meteorological stations which are both representing the watersheds. Therefore, precipitation amounts $(1076.7 \mathrm{~mm})$ were taken from only one station nearest to the both watersheds (Table 1).

In the present study, slope length $(l)$ and slope steepness $(s)$ factors used to calculate $L$ and $S$ in the USLE were also obtained using GIS (Table 1 ). The R factor and $K$ factor (Table 1) were provided from data of previous studies obtained in the same area by Doğan and Güçer (1976), Arnoldus (1977), Balcı (1996) and Cebel et al. (2013). WS
I was found to have experienced almost no human impacts, whereas WS II suffered from intensive human impacts. The $\mathrm{K}$ factor representing the red Mediterranean soils (0.12) was used owing to the surface depth of the soil (Cebel et al., 2013) both in WS I and WS II. The soil group was the one of moderately erodible soils for both WS I and WS II (Doğan and Güçer, 1976) (Table 1). Data relating to $L$ and $S$ of $l$ and $s$ (Table 1) were determined to calculate equations from previous studies (Eqs. 1 and 2) (Balc1, 1976).

The values for the $C$ and $P$ factors reported by Balc1 (1996) were determined for a study area with properties identical to those of the existing study described here; accordingly, they were considered to be most appropriate for use in this study (Table 2). The USLE can be presented as follows:

$A=K R L S C P$,

where $A$ is the annual soil loss $\left(\mathrm{tha}^{-1} \mathrm{yr}^{-1}\right)$. In Eq. (1), the impacts of slope length and steepness were usually combined into one single factor (Randle et al., 2003), known as the topographic factor (LS) (Balc1, 1996), which can be computed 
Table 2. Cropping management $(C)$ and erosion control practice $(P)$ factors for WS I (adapted from Arnoldus (1977) and Balc1 (1996).

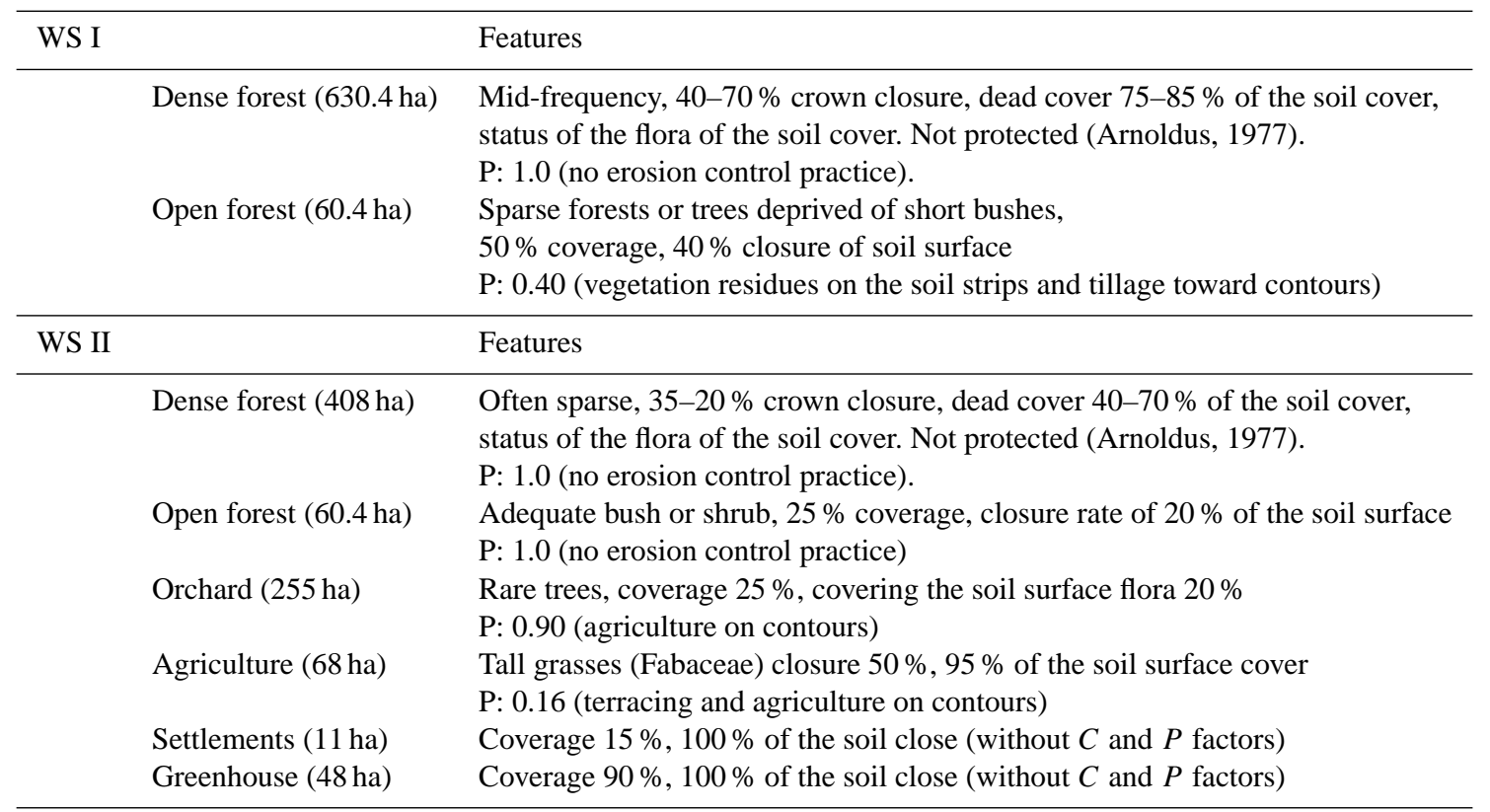

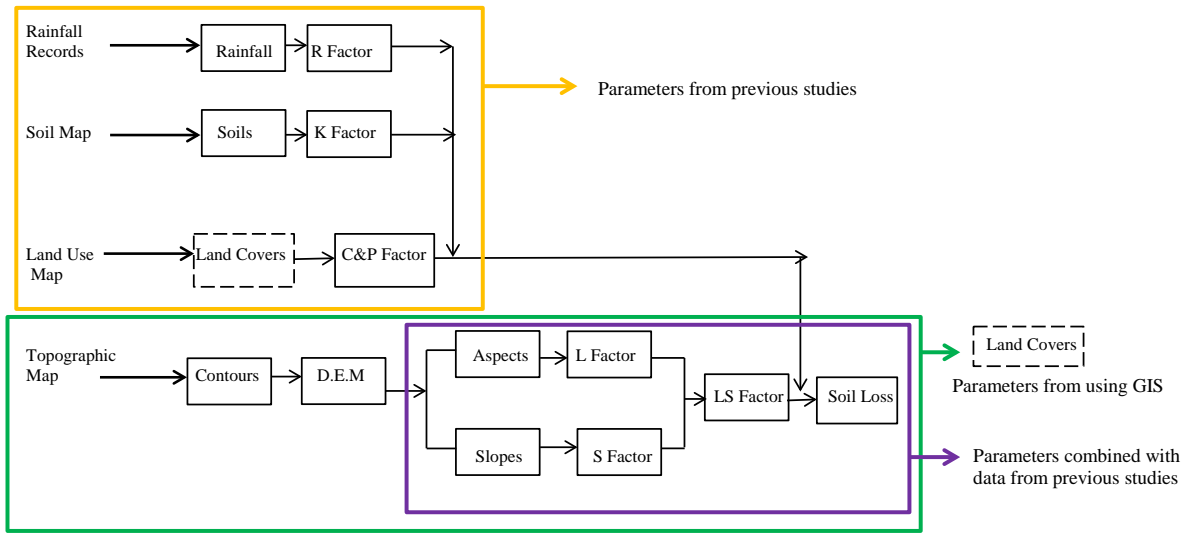

Figure 2. Flow chart to estimate a coefficient using the USLE in the study (adapted from Fistikogli and Harmancioglu, 2002).

as follows:

$\mathrm{LS}=l^{0.5}\left(0.0136+0.00965 s+0.00138 s^{2}\right)$.

$s(\%)$ and $l(\mathrm{~m})$ calculated to the $L S$ factor for the studied watersheds were 1.32 for WS I and 0.714 for WS II (Table 3). As can be seen in these tables, the $K, R, C$, and $P$ factors established in the USLE for dense forests, open forests, orchards, and agricultural lands in both watersheds were obtained from previous studies (Doğan and Güçer, 1976; Arnoldus, 1977; Balc1, 1996; Doğan et al., 2000; Cebel et al., 2013). Finally, all the factors of the USLE were used to determine the total annual soil loss (Table 3 ). It has been established that the $K, R, L$ and $S$ factors were represented in a distinct layer in the USLE (LIFE+ Programme, 2011), which explains why the potential and actual erosion amounts were not calculated for comparison (Table 3). It is well known that actual erosion values cannot be calculated for settlements and greenhouses. This is because these areas do not have enough vegetation cover to influence the calculations. The USLE can only be used to calculate actual erosion values; however, potential erosion calculations do not take into account land use and vegetation. As the two values cannot be compared, potential erosion values were used for settlement and greenhouse areas.

\section{Data analysis}

The available soil loss amounts and the degree of socioeconomic factors for each of the watersheds were calculated with consideration given to previous studies. Thus, it was ex- 
Table 3. Factors affecting the USLE and the amount of soil loss for WS I. Rainfall factor $(R)$; soil erodibility factor $(K)$; topographic factor $(L S)$; cropping management factor $(C)$; and erosion control practice factor $(P)$.

\begin{tabular}{|c|c|c|c|c|c|c|c|c|}
\hline Watershed & Land use & $R$ & $K$ & $L S$ & $C$ & $P$ & $\begin{array}{l}A \\
\left(\mathrm{Mgha}^{-1} \mathrm{yr}^{-1}\right)\end{array}$ & $\begin{array}{l}\text { Total soil loss } \\
\text { amounts in terms of } \\
\text { land use }\left(\mathrm{Mg} \mathrm{yr}^{-1}\right)\end{array}$ \\
\hline \multirow[t]{2}{*}{ WS I } & Dense forest (ha) & 415.2 & 0.12 & 1.32 & 0.01 & 1.0 & 660 & 414800 \\
\hline & Open forest (ha) & 415.2 & 0.12 & 1.32 & 0.14 & 0.40 & 3683 & 222450 \\
\hline \multirow[t]{6}{*}{ WS II } & Dense forest (408 ha) & 415.2 & 0.12 & 0.714 & 0.02 & 1.0 & 712 & 8449680 \\
\hline & Open forest ( $8 \mathrm{ha})$ & 415.2 & 0.12 & 0.714 & 0.18 & 1.0 & 6403 & 1490880 \\
\hline & Orchard (255 ha) & 415.2 & 0.12 & 0.714 & 0.23 & 0.90 & 7364 & 54651600 \\
\hline & Agriculture (68 ha) & 415.2 & 0.12 & 0.714 & 0.003 & 0.16 & 17 & $\begin{array}{l}33800 \\
\text { Potential erosion }\end{array}$ \\
\hline & Settlement (11 ha) & 415.2 & 0.12 & $\begin{array}{l}\text { l: } 13.05 \\
\text { s: } 14.82 \%\end{array}$ & - & - & - & 1072830 \\
\hline & Greenhouse (48 ha) & 415.2 & 0.12 & $\begin{array}{l}\text { l: } 13.05 \\
\text { s: } 14.82 \%\end{array}$ & - & - & - & 4681440 \\
\hline
\end{tabular}

pected that a coefficient could be added to the current USLE equation. A simulation method was used based on Fortran programming.

All data of the study area were used to evaluate the contributions of the socioeconomic factors to the total annual erosion $(A)$ and find a coefficient in the USLE. $C$ and $P$ values for the socioeconomic factors in the USLE were obtained from the average of $C$ and $P$ values taking their total of all existing values. In other words, to find the coefficient that represents the socioeconomic factors' impact on soil erosion, an average value was obtained from all total $C$ and $P$ values. Subsequently, $C$ and $P$ factors were analyzed to find their averages. The contributions of socioeconomic factors to the total annual soil loss amounts were established. In the process, simple mathematical equations were used to find the coefficient (Fig. 3). These steps were shown on a flow chart modified from Fistikogli and Harmancioglu (2002) to check over the USLE and soil loss estimation, and finally mathematical processes to find a coefficient.

The calculation of the factors affecting soil loss amounts for WS I was completed using the traditional USLE, because this watershed was assumed not to be under the influence of any human impact. However, the annual amount of soil loss in WS II was determined using both physical factors used in the USLE and the modified coefficient in the USLE.

The sequence of calculation steps aimed to generate the required coefficient. Accordingly, each progression was defined separately as follows.

The total number of people and animals in the settlements were described as the socioeconomic factor (Se); it was used to estimate the amount of soil loss in the settlement $\left(\mathrm{Se}_{\mathrm{E}}\right)$. This equation used the ratio of settlement numbers in total watershed area (ha) multiplied by the amount of soil loss $(A)$ from the USLE (step 1). The second process was stated as an effect of socioeconomic factors $\left(\right.$ Soc-e- $\left.F_{E}\right)$, i.e., the amount of soil loss due to socioeconomic factors were calculated using the amount of soil loss per person $\left(\mathrm{Pp}_{\mathrm{E}}=\mathrm{Se}_{\mathrm{E}} /\right.$ total $\left.\mathrm{Pp}\right)$ and per animal $\left(\mathrm{An}_{\mathrm{E}}=\mathrm{Se}_{\mathrm{E}} /\right.$ total $\left.\mathrm{An}\right)($ step 2) to find the contribution of socioeconomic factors as settlements in $\mathrm{A}$ $\left(\mathrm{Mg} \mathrm{ha}^{-1} \mathrm{yr}^{-1}\right)$ (step 3). The ratio of Soc-e-F $\mathrm{F}_{\mathrm{E}}$ to A gave the coefficient (step 4). This coefficient also represented the total $C$ and $P$ values contributing to the averages of the available $C$ and $P$ used in the study (Fig. 3).

\section{Results and discussion}

The total area and altitude of the WS I and WS II were 700 and 800 ha, and 664 and $316 \mathrm{~m}$, respectively. In addition, slope was $27.43 \%$ in WS I and $14.82 \%$ in WS II (Table 1). Crown closure of WS I was found to be 40-70 and 20-35\% for WS I and WS II, respectively. However vegetation covers except for the lake areas in WS I and WS II were 68 and $40 \%$, respectively (Table 1). We assumed that there was almost no human impact on WS I; however, WS II had an intensive human impact. But it should be accepted that the dense forest changed into the open forest by illegal logging, which can be called a human impact. The previous studies (Doğan and Güçer, 1976; Balc1, 1996; Cebel et al., 2013) had also assumed that open forest already included illegal logging. According to even only these data, it should be expected that the amount of soil loss in WS II would be considerably more than in WS I even though it had a lower percentage of slope. Similarly, dead cover on soil in WS I was $75-85 \%$, whereas in WS II it was 40-70\% (Tables 2 and 3). Therefore, the $C$ and $P$ factors for WS I and WS II were selected as $0.025-0.14$ and 1.0 (without erosion control management practices) -0.40 (with erosion control management practices) from previous studies, respectively. In this case, it was expected that the amount of soil loss in WS I could be less than WS II due to vegetation cover and structure. Zhongming et al. (2010) also stated that vegetation cover has an important role since the rate of soil erosion decreases as the vegetation cover increases. It also reduces the erosive impact of precipitation, which is the same in both watersheds. For 


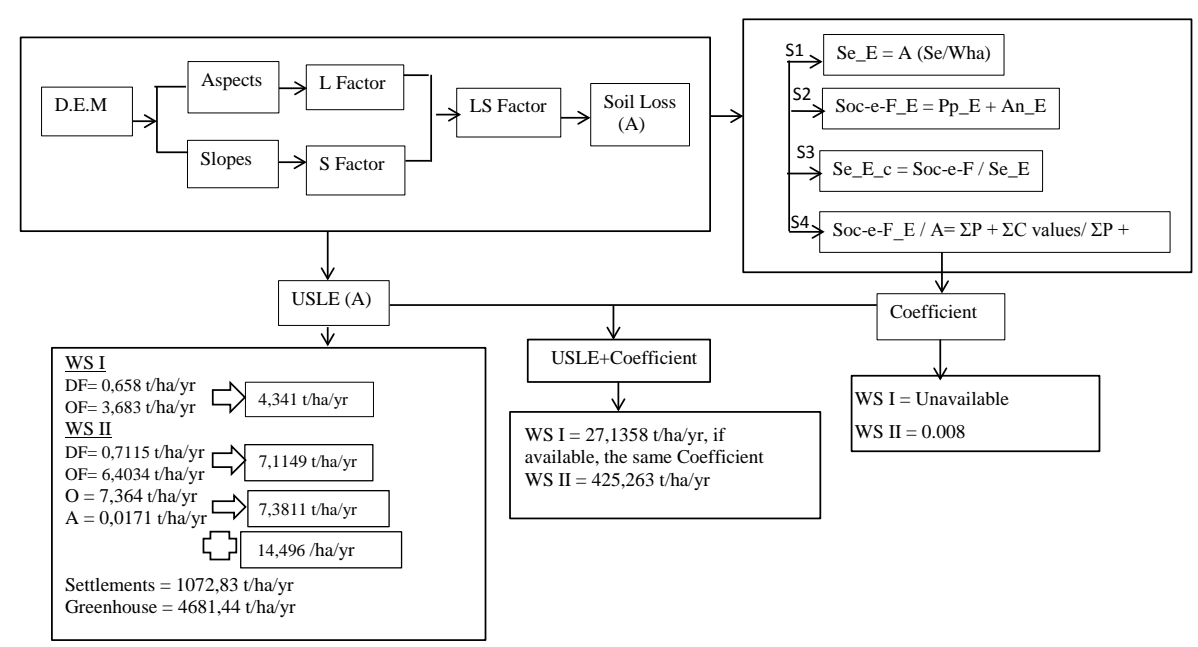

Figure 3. Steps calculating coefficient modified in the USLE that represents the contribution of socioeconomic factors to soil loss. The factors of the USLE estimated using GIS and working steps as mathematical processes to find a coefficient that contributed socioeconomic factors such as the number of people and animals $\left(A=\mathrm{tha}^{-1} \mathrm{yr}^{-1}\right.$; Se - Settlements; Wha - size of WS II; Se $\mathrm{E}-$ effect of settlements on erosion; $\mathrm{Pp}$ - people population; $\mathrm{Pp}_{\mathrm{E}}$ - effect of people population on erosion; An - animal numbers; An $\mathrm{E}$ - effect of animal numbers on erosion; Soc-e- $\mathrm{F}_{\mathrm{E}}-$ effect of socioeconomic factors on erosion; $\mathrm{Se}_{\mathrm{E}}-\mathrm{c}-$ contribution to erosion from settlements )

all that, LS in WS I and WS II was 1.31 and 0.714 , respectively. This means that undoubtedly the steeper and longer the slope, the higher the risk for erosion in WS II. Furthermore, the $P$ factor in WS II was 0.40 , so it would definitely result in lower soil loss (Tables 1 and 2). In addition to all these, tillage methods used such as terraces and contours in agriculture and orchard land uses probably reduced the slope length and increased soil water moisture in WS II, so they would result in lower soil losses (USDA, 2011) and higher water moisture in those for WS II and for open forest in WS I because of vegetation residues and contours.

In the present study we considered the number of humans and livestock in terms of affecting the amount of soil loss in WS II. These values, which consisted of 2650 people and 3100 livestock according to the 2007 census year (source: village headman, M. Akman, personal communication, 2014), were used to calculate their effects or contribution to the amount of soil loss as socioeconomic factors in the area. Boardman et al. (2003) stated that the socioeconomic factors, such as human population and livestock, contribute to soil loss and that physical factors drive soil erosion.

Data analysis was conducted in order to estimate the contribution of settlements as coefficient to WS I and WS II. At the first stage, all mentioned data were used to estimate to actual erosion, except for settlement and greenhouse areas due to not having vegetation cover, using the USLE. After this stage, human and livestock impacts per unit of the amount of soil loss were established in the equation. Then the contribution of settlement to the total amount of soil erosion was identified, being calculated in terms of kilograms. At the end of this stage, the amount of soil loss was calculated using the USLE for WS I and WS II. All different $C$ and $P$ factors in the equation were simulated with combinations of them. After then, the means of the coefficients for each combination with the amount of soil loss were determined. The means of these coefficients were identified as the correction coefficient of socioeconomic factors, which contribute to the amount of soil loss in the USLE. The range of determining the coefficient through simulation was developed as a mathematical equation. The coefficient, which can be added as a correction coefficient, was calculated as 0.008 . Therefore, the modified coefficient with the USLE can be represented as $0.008 A+A$, which determined the correction coefficient, and stated as $\pm \mathrm{SE}=0.008 \pm 0.000944$. This means that the rate of $0.8 \%$ could increase or decrease the rate of $0.000944( \pm 11.8 \%$ of the coefficient).

The calculated results of similar land uses in selected two watersheds showed that dense forests and open forests in the total area were $90-51 \%$ in WS I and $9-1 \%$ in WS II, while the amount of erosion of those soils was 660 $3683 \mathrm{Mg} \mathrm{ha}^{-1} \mathrm{yr}^{-1}$ in WS I and $712-718 \mathrm{Mg} \mathrm{ha}^{-1} \mathrm{yr}^{-1}$ in WS II using the USLE (Table 3). Furthermore, the amount of soil loss using a modified coefficient of $0.08 \%$ was 665 $3713 \mathrm{Mg} \mathrm{ha}^{-1} \mathrm{yr}^{-1}$ in WS I while $712-718 \mathrm{Mg} \mathrm{ha}^{-1} \mathrm{yr}^{-1}$ in WS II (Table 4). The results showed that the increase from modifying the coefficient was $5-30 \mathrm{Mg} \mathrm{ha}^{-1} \mathrm{yr}^{-1}$ in WS I and $6-51 \mathrm{Mg} \mathrm{ha}^{-1} \mathrm{yr}^{-1}$ in WS II (Tables 3 and 4). Although these increases may seem less per hectare, considering the increase in the total area of each land use, it may be understood that the amount of soil loss would be very much in both watersheds. In addition, the amount of soil loss in orchard (225 ha) and agricultural land (68 ha) was found $7364 \mathrm{Mg} \mathrm{ha}^{-1} \mathrm{yr}^{-1}$ and $17 \mathrm{Mg} \mathrm{ha}^{-1} \mathrm{yr}^{-1}$ in WS II, respectively. As mentioned above, the total amount of soil erosion 
Table 4. The amount of soil loss without and with modified coefficient in the USLE.

\begin{tabular}{|c|c|c|c|c|}
\hline \multirow[t]{2}{*}{ WS I } & \multirow[t]{2}{*}{$\begin{array}{l}\text { Area } \\
\text { (ha) }\end{array}$} & $\begin{array}{l}\text { The amount of soil loss with- } \\
\text { out socioeconomic factors in } \\
\text { the USLE }\left(\mathrm{Mg} \mathrm{ha}^{-1} \mathrm{yr}^{-1}\right)\end{array}$ & $\begin{array}{l}\text { The amount of soil loss with } \\
\text { modified coefficient in the } \\
\text { USLE }\left(\mathrm{Mg} \mathrm{ha}^{-1} \mathrm{yr}^{-1}\right)\end{array}$ & $\begin{array}{l}\text { Difference between two amounts } \\
\text { of soil erosion }\left(\mathrm{Mg} \mathrm{ha}^{-1} \mathrm{yr}^{-1}\right) \text { and } \\
\text { contribution of coefficient }(\%)\end{array}$ \\
\hline & & $\mathrm{A}\left(\mathrm{Mg} \mathrm{ha}^{-1} \mathrm{yr}^{-1}\right)$ & $0.008 A+\mathrm{A}$ & $(0.008 A+A)-A$ \\
\hline Dense forest & 630.4 & 660 & 665 & 5 \\
\hline Open forest & 60.4 & 3683 & 3713 & 30 \\
\hline WS II & Area (ha) & $A\left(\mathrm{Mg} \mathrm{ha}^{-1} \mathrm{yr}^{-1}\right)$ & $0.008 A+A$ & $(0.008 A+A)-A$ \\
\hline Dense forest & 408 & 712 & 718 & 6 \\
\hline Open forest & 8 & 6403 & 6454 & 51 \\
\hline Orchard & 255 & 7364 & 7423 & 59 \\
\hline Agriculture & 68 & 17 & 17.15 & 0.15 \\
\hline
\end{tabular}

for settlements (11 ha) and greenhouses (48 ha) was calculated as potential erosion owing to the lack of vegetation cover in these land uses (LIFE+ Programme, 2011; Savac1, 2012). The amount of erosion of their soils were calculated as $1072830 \mathrm{Mg} \mathrm{yr}^{-1}$ and $4681440 \mathrm{Mg} \mathrm{yr}^{-1}$ using $l$ and $s$ (13.5 $\mathrm{m}$ and $14.82 \%$ ), respectively (Table 3 ). This result also shows that vegetation cover plays a very important role due to land use surface. Jones et al. (2004) stated that its role is a factor mitigating soil erosion by surface water. Mandal and Maiti (2015) also stated that land use and land cover play a significant role in influencing surface runoff and slope material saturation. Furthermore, it was stated that socioeconomic demand of the local people would aggravate the problems of soil loss and slope failure. According to the researchers, surface water is an indicator of potential erosion and instability. In this context, it is possible and likely that forest and open forest areas of WS II might be damaged in the case of more settlements due to more erosion problems. Changes in the amount of soil loss determined with the new equation in the present study were considered to be the result of human and animal settlements. The values of the amount of soil loss with the modified coefficient in the USLE are symbolized in Table 4. Unquestionably, the amount of soil loss from the USLE depended on biophysical factors as well as socioeconomic factors interacting with other factors such as cropping management $(C)$ and erosion control practice $(P)$ factors; however, in previous studies human population and livestock numbers were not considered as erodible factors in the USLE. In view of the above lack, these erodible factors, called settlement in the present study, were used to find a coefficient. As Okun et al. (1989) clearly pointed out, settlements are connected to ecological systems and environmental services because the exploitation of natural resources directly impacts the economical lifeline of the communities, ecological support of their system and sustainability of their communities. Considering the sustainability of watersheds containing these socioeconomic factors, there is a need to understand their contribution to erosion in the USLE. Jin- gan et al. (2005) and Halim et al. (2007) reported that biophysical factors contributed about $65 \%$ to erosion, while socioeconomic factors accounted for about $35 \%$. In the present study, the coefficient showed that socioeconomic factors affected the amount of soil loss in the watersheds, even if only slightly (Table 4). Undoubtedly, all factors change depending on biophysical conditions of watersheds such as topography, soil properties and climate as well as their socioeconomic factors. Therefore, in the present study, the determined coefficient represents just WS II.

\section{Conclusions}

The settlement area in WS II is very small, such that the contribution of socioeconomic factors appears limited. Admittedly, $0.8 \%$ of the increase could be very minimal. However, it is highly possible that the amount of soil loss would increase in large settlement areas. It could be accepted that the coefficient is a safety factor for WS II due to its unique properties. The decisions of the local authorities should be considered in this context, since Antalya is a resort area but densely populated and has terrible air temperature in the summers. Hence, there is an increasingly tendency to build settlements in the mountainous areas in the region. Therefore, it is highly likely that risk of soil loss in mountainous areas described as plateau would increase in the future.

There is a need to improve existing methods to estimate the amount of soil loss. This approach will be studied to obtain coefficients representing all socioeconomic factors in many watersheds. Thence, it will be possible to develop a new method that allows reducing soil erosion risks and improving land management plans in watersheds.

Soil erosion is a key concern affecting all areas of the world and is very accelerated by human activities. Adverse conditions caused by this phenomenon can be decreased with the use of strategies to restore land management programs.

Furthermore, mountainous areas will be opened for intensive settlement when the city center of Antalya is exposed 
to extreme temperatures due to the population growth and changes in climate that should be expected. To cope with these issues, land management, restoration and rehabilitation programs should be undertaken in those areas.

This research will also help to provide a new approach for assessing the restoration, rehabilitation and land management strategies, with the aim of developing a safety coefficient to develop land use plans and support watershed planners in arid and semiarid regions, which are considered to threaten the soil erosion.

Edited by: A. Cerdà

\section{References}

Ali, S. and Sharda, V. N.: Evaluation of the Universal Soil Loss Equation (USLE) in semi-arid and sub-humid climates of India, Appl. Eng. Agric., 21, 217-25, 2005.

Arnoldus, H. M. J.: Predicting soil losses due to sheet and rill erosion, FAO Conservation Guide 1, Guidelines for Watershed Management, FAO, Rome, Italy, 1977.

Balc1, N.: Soil Conservation, Istanbul University Faculty of Forestry, Department of Watershed Management, University Publication No: 3947, Faculty Publication No: 439, ISBN 975404-423-6, Istanbul, Turkey, 1996 (in Turkish).

Berendse, F., van Ruijven, J., Jongejans, E., and Keesstra, S.: Loss of Plant Species Diversity Reduces Soil Erosion Resistance, Ecosystems, 18, 881-888, doi:10.1007/s10021-015-98696,2015 .

Boardman, J., Poesen, J., and Evans, R.: Socio-economic factors in soil erosion and conservation, Environ. Sci. Policy, 6, 1-6, doi:10.1016/S1462-9011(02)00120-X, 2003.

Brevik, E. C., Cerdà, A., Mataix-Solera, J., Pereg, L., Quinton, J. N., Six, J., and Van Oost, K.: The interdisciplinary nature of soil, Soil, 1, 117-129, doi:10.5194/soil-1-117-2015, 2015.

Çanga, M.: Soil Erosion: Universial soil loss equation, Chapter 5, available at: http://arsiv.agri.ankara.edu.tr/soil_sciences/ 1235_Bolum_5_Toprak_Kayiplarinin_Tahmini.pdf (last access: 23 May 2015), 2006 (in Turkish).

Cao, L., Zhang, K., Dai, H., and Liang, Y.: Modeling interrill erosion on unpaved roads in the Loes Plateau of China, Land Degrad. Dev., first published online: 10 October 2013, doi:10.1002/ldr.2253, 2014.

Cardinale, B. J., Duff, J. E., Gonzalez, A., Hooper, D. U., Perrings, C., Venail, P., Narwani, A., Mace, G. M., Tilman, D., Wardle, D. A., Kinzig, A. P., Daily, G. C., Loreau, M., Grace, J. B., Larigauderie, A., Srivastava, D. S., and Naeem, S.: Biodiversity loss and its impact on humanity, Nature, 486, 59-67, 2012.

Castro, F. C., Cochrane, T. A., Norton, L. D., Caviglione, J. H., and Johansson, L. P.: Land degradation assessment: tools and techniques for measuring sediment load, Agric. Research Service, Purdue University, West Lafayette, USA, 2001.

Cebel, H., Akgül, S., Doğan, O., and Elbaşı, F.: K factors of erosion sensitivity of Turkey soil groups, J. Soilwater, 2, 30-45, 2013.

Cerdà, A.: Aggregate stability against water forces under different climates on agriculture land and scrubland in southern Bolivia, Soil Till. Res., 36, 1-8, 2000.
Cerdà, A. and Lasanta, T.: Long-term erosional responses after fire in the Central Spanish Pyrenees: Water and sediment yield, Catena, 60, 59-80, doi:10.1016/j.catena.2004.09.006, 2005.

Doğan, O. and Güçer, C.: The causes of water erosion-formation and determining of soil loss using Universal Soil Loss Equation, Ministry of Village Works, General Directorate of Soilwater, Central of Soilwater Research Institute Publications, General Publication No. 41, Technical Publication No. 24, Ankara, Turkey, 1976.

Doğan. O., Cebel, H., Küçükçakar, N., and Akgül, S.: K factors of erosion sensitivity of Turkey Soil Groups, Prime Ministry General Directorate of APK Department of Rural Services, Research Directorate of Soil and Water Resources, Publication No. 111, Guide No. 17, Ankara, Turkey, 2000 (in Turkish).

Eswaran, H., Lal, R., and Reich, P. F.: Land degradation: an overview, in: Responses to Land Degradation, edited by: Bridges, E. M., Hannam, I. D., Odeman, L. R., Pening de Vries, F. W. T., Scherr, S. J., and Sompatpanit, S., Proc. 2nd International Conference on Land Degradation and Desertification, Khon Kaen, Thailand, Oxford Press, New Delhi, India, 2001.

Evans, R.: Soil erosion and its impacts in England and Wales, Friends of the Earth, London, UK, 1996.

Fistikogli, O. and Harmancioglu, N. B.: Integration of GIS with USLE in assessment of soil erosion, Faculty of Engineering, Dokuz Eylul University, Izmir, Turkey, 2002.

Galdino, S., Sano, E. E., Andrade, R. G., Grego, C. R., Nogueira, S. F., Bragantini, C., and Flosi, A. H. G.: Large scale modelling of soil erosion with RUSLE for conservationist planning of degraded cultivated Brazilian pastures, Land Degrad. Dev., first published online: 13 August 2015, doi:10.1002/ldr.2414, 2015.

Ganjegunte, G. K., Sheng, Z., and Clark, J. A.: Soil salinity and sodicity appraisal by electromagnetic induction in soils irrigated to grow cotton, Land Degrad. Dev., 25, 228-235, doi:10.1002/ldr.1162, 2014.

García-Orenes, F., Roldán, A., Mataix-Solera, J., Cerdà, A., Campoy, M., Arcenegui, V., and Caravaca, F.: Soil structural stability and erosion rates influenced by agricultural management practices in a semi-arid Mediterranean agro-ecosystem, Soil Use Manage., 28, 571-579, doi:10.1111/j.1475-2743.2012.00451.x, 2012.

Giménez Morera, A., Ruiz Sinoga, J. D. Y., and Cerdà, A.; The impact of cotton geotextiles on soil and water losses in Mediterranean rainfed agricultural land, Land Degrad. Dev., 21, 210217, doi:10.1002/ldr.971, 2010.

Grimaldi, S., Angeluccetti, I., Coviello, V., and Vezza, P.: Costeffectiveness of soil and water conservation measures on the catchment sediment budget-the Laaba Watershed Case Study, Burkina Faso, Land Degrad. Dev., doi:10.1002/ldr.2212, 2013.

Halim, R., Clemente R. S., Routray J. K., and Shrestha R. P.: Integration of biophysical and socio-economic factors to assess soil erosion hazard in the upper Kaligarang watershed, Indonesia, Land Degrad. Dev., 18, 453-469, doi:10.1002/ldr.774, 2007.

Harden, C. P.: Soil erosion and sustainable mountain development: experiments, observations, and recommendations from the Ecuadorian Andes, Mt. Res. Dev., 21, 77-83, 2001.

Haregeweyn, N., Poesen, J., Nyssen, J., De Wit, J., Haile, M., Govers, G., and Deckers, S.: Reservoirs in Tigray (northern Ethiopia): characteristics and sediment deposition problems, Land Degrad. Dev., 17, 211-230, doi:10.1002/ldr.698, 2006. 
Haregeweyn, N., Poesen, J., Verstraeten, G., Govers, G., de Vante, J., Nyssen, J., Deckers, J., and Moeyersons, J.: Assessing the performance of a spatially-distributed soil erosion and sediment delivery model (WATEM/SEDEM) in northern Ethiopia, Land Degrad. Dev., 24, 188-204, 2013.

Jayarathne, K. D. B. L., Dayawansa, N. D. K., and De Silva, R. P.: GIS based analysis of biophysical and socio-economic factors for land degradation in Kandaketiya DS, Division, Tropical Agricultural Research, 21, 361-367, 2010.

Jingan, S., Jiupai, N., Chaofu, W., and Xie Deti, W.: Land use change and its corresponding ecological responses: a review, J. Geogr. Sci., 15, 305-328, 2005.

Jones, C., Carvalho, L. M. V., Higgins, V. R., Waliser, D. E., and Schemm, J. K. E.: Climatology of tropical intraseasonal convective anomalies: 1979-2002, American Meteorological Society, 523-539, doi:10.1175/15200442(2004)017<0523:COTICA>2.0.CO;2, 2004.

Keesstra, S. D., Geissen, V., van Schaik, L., Mosse., K., and Piiranen, S.: Soil as a filter for groundwater quality, Current Opinions in Environmental Sustainability, 4, 507-516, doi:10.1016/j.cosust.2012.10.007, 2012.

Kertész, Á.: The global problem of land degradation and desertification, Hung. Geogr. Bull., 58, 19-31, 2009.

Lal, R.: Deforestration of tropical rainforest and hydrological problems, in: Tropical Agricultural Hydrology, edited by: Lal, R. and Russell, E. W., J. Wiley and Sons, Chichester, UK, 131-140, 1981.

Lal, R.: Soil Erosion Research Methods (Ed.), St Lucie Press, Delray Beach, FL, USA, 1994.

Lal, R.: Restoring Soil Quality to Mitigate Soil Degradation, Sustainability, 7, 5875-5895, doi:10.3390/su7055875, 2015.

Larson, W. E., Lindstrom, M. J., and Schumacher, T. E.: The role of severe storms in soil erosion: a problem needing consideration, $\mathrm{J}$. Soil Water Conserv., 52, 90-95, 1997.

Leh, M. D. K.: Quantification of sediment sources in a mixed land use watershed: A remote sensing and modeling approach, Ph.D. Thesis, University of Arkansas, Fayetteville, AR, USA, 2011.

Leh, M., Bajwa, S., and Chaubey, I.: Impact of land use change on erosion risk: and integrated remote sensing geopraphic information system and modeling methodology, Land Degrad. Dev., 24, 409-421, doi:10.1002/ldr.1137, 2013.

Lieskovský, J. and Kenderessy, P.: Modelling the effect of vegetation cover and different tillage practices on soil erosion in vineyards: A case study in Vráble (Slovakia) using WATEM/SEDEM, Land Degrad. Dev., 25, 288-296, doi:10.1002/ldr.2162, 2014.

LIFE+ Programme (European Commission): Soil Erosion Risk USLE Model, Explanation of the Data and Model of Soil Erosion Uploaded in the Sicilian Framework of the SMS, LIFE08ENV/IT/000428, available at: http://www.soilpro.eu/assets/doc.html (last access: 7 August 2015), 2011.

Mandal, D. and Sharda, V. N.: Appraisal of soil erosion risk in the Eastern Himalayan Region of India for soil conservation planning, Land Degrad. Dev., 24, 430-437, doi:10.1002/ldr.1139, 2013.

Mekonnen, M., Keesstra, S. D., Stroosnijder, L., Baartman, J. E. M., and Maroulis, J.: Soil conservation through sediment trapping: a review, Land Degrad. Dev., 26, 544-556, doi:10.1002/ldr.2308, 2014.

Mukhopadhyay, S. and Maiti, S. K.: Soil CO2 flux in grassland, afforested land and reclaimed coal mine overburned dumps: A case study, Land Degrad. Dev., 25, 216-227, doi:10.1002/ldr.1161, 2014.

Narain, P., Khybri, M. L., Tomar, H. P. S., and Sindhwal, N. S.: Estimation of runoff, soil loss and USLE parameters for Doon Valley, Indian J. Soil Conserv., 22, 1-9, 1994.

Okun, D., Crosson, P., Cummings, B., Braatz, S., Wilson, M., and Eigen, J.: Natural resources in regional development, in Guidelines for settlements planning and management, Environmental Consideration in Regional Planning and Management (III), 83473, available at: www.https://books.google.com.tr (last access: 6 July 2015), 1989.

OSİB (Ministry of Environment and Forests).: Turkey's National Action Programme to Combat Desertification, Unit of National Coordination for Combat Desertification, Ministry of Environment and Forests Publications No. 250, ISBN 975-7347-51-5, Ankara, Turkey, available at: http://www.cevreorman.gov.tr (last access: 6 July 2015), 2005 (in Turkish).

Özhan, S.: Watershed Management, Istanbul University Faculty of Forestry, Department of Watershed Management, IU Rectorate Publication No: 4510, Faculty Publication No: 481, ISBN 975404-739-1, 313, Istanbul, Turkey, 2004 (in Turkish).

Pimentel, D.: World Soil Erosion and Conservation, Cambridge University Press: Cambridge, UK, 1993.

Pimentel, D. and Burgess, M.: Soil erosion threatens food production, Agriculture, 3, 443-463, 2013.

Randle, T. J, Yang, C. T., and Daraio, J.: Erosion and Reservoir Sedimentation, Chapter 2, 1-94, available at: http://www.usbr.gov/ pmts/sediment/kb/Chapter2.pdf (last access: 15 August 2015), 2003.

Savac1, G.: Determination of Erosion Risk Maps According to Corine Methodology of Goz and Haman Watersheds in Kahramanmaras, Kahramanmaras Sutcu Imam University Graduate School of Natural and Applied Science, Master's Thesis, Kahramanmaras, available at: http://www.irfanakar.com/turkish/pdf2/ ua/tezler/Dogal_Afetler/1\%2812\%29.pdf (last access: $20 \mathrm{Au}-$ gust 2015), 2012 (in Turkish).

Sharda, V. N., and Ali, S.: Evaluation of the Universal Soil Loss Equation in semi-arid and sub-humid climates of India using stage-dependent C-factor, Indian J. Agr. Sci., 78, 422-427, 2008.

Tesfahunegn, G. B.: Soil quality indicators response to land use and soil management systems in northern Ethiopia's catchment, Land Degrad. Dev., doi:10.1002/ldr.2245, 2013.

TUIK (Turkish Statistical Institute): Key Indicators: Population of Turkey (2013), available at: http://www.tuik.gov.tr (last access: 6 July 2015), 2014 (in Turkish).

USDA (The U.S. Department of Agriculture).: National Agronomy Manual, 190-V-NAM, 4th Ed., available at: http://www.nrcs.usda.gov/wps/PA_NRCSConsumption/ download?cid=stelprdb1043210\&ext=pdf (last access: 6 July 2015), 2011.

Van der Waal, B. W., Rowntree, K. M., and Radlof, S. E.: The effect of Acacia mearnsii invasion and clearing on soil loss in the Kouga Mountains, Eastern Cape, South Africa, Land Degrad. Dev., 23, 577-585, doi:10.1002/ldr.2172, 2012. 
Vanmaercke, M., Poesen, J., Maetens, W., de Vente, J., and Verstraeten, G.: Sediment yield as a desertification risk indicator, Sci. Total Environ., 409, 1715-1725, doi:10.1016/j.scitotenv.2011.01.034, 2011.

Van Rompaey, A. J. J. and Govers, G.: Data quality and model complexity for continental scale soil erosion modelling, International Journal of GIS, 16, 663-680, doi:10.1080/13658810210148561, 2002.

Vanwalleghem, T., Infante Amate, J., González de Molina, M., Soto Fernández, D., and Gómez, J. A.: Quantifying the effect of historical soil management on soil erosion rates in Mediterranean olive orchards, Agr. Ecosyst. Environ., 142, 341-351, doi:10.1016/j.agee.2011.06.003, 2011.

Veldkamp, A. and Lambin, E. F.: Predicting land-use change, Agr. Ecosyst. Environ., 85, 1-6, 2001.

Verburg, P. H., Schot, P. P., Dijst, M. J. and Veldkamp, A.: Land use change modelling: Current practice and research priorities, GeoJournal, 61, 309-324, 2004.

Wang, Y. Q., and Shao, M. A.: Spatial variability of soil physical properties in a region of the loess plateau of PR China subjet to wind and water erosion, Land Degrad. Dev., 24, 296-304, doi:10.1002/ldr.1128, 2013.

Wildemeersch, J. C. J., Timmerman, E., Mazijn, B., Sabiou, M., Ibro, G., Garba, M., and Cornelis, W.: Assessing the constraints to adopt water and soil conservation techniques in tillaberi, Niger, Land Degrad. Dev., 26, 491-501, doi:10.1002/ldr.2252, 2015.

Wischmeier, W. H., and Smith, D. D.: Soil-Loss Estimation as a Tool in Soil and Water Management Planning, Institute of Association of Scientific Hydrology, Publication No. 59, 148-159, 1962.
Wischmeier, W. H., and Smith, D. D.: Predicting Rainfall-Erosion Losses from Cropland East of the Rocky Mountains, U.S. Department of Agriculture, Agriculture Handbook No. 282, p. 48, 1965.

Wischmeier, W. H., and Smith, D. D.: Predicting Rainfall Erosion Losses-Guide to Conservation Planning, U.S. Department of Agriculture, Agriculture Handbook No. 537, 26-27, 1978.

Yazdani, M., Monavari, S. M., Omrani, G. A., Shariat, M., and Hosseini, S. M.: Landfill site suitability assessment by means of geographic information system analysis, Solid Earth, 6, 945-956, doi:10.5194/se-6-945-2015, 2015.

Young, A.: Land degradation in South Asia: its severity, causes, and effects upon the people, Final report, Economic and Social Council, FAO, UN, Rome, Italy, 1993.

Zhao, G., Mu, X., Wen, Z., Wang, F., and Gao, P.: Soil erosion, conservation, and eco-environment changes in the Loess Plateau of China, Land Degrad. Dev., 24, 499-510, doi:10.1002/ldr.2246, 2013.

Zhongming, W., Lees, B. G., Jiao Feng, J., Wanning, L., and Haijing, S.: Stratified vegetation cover index: A new way to assess vegetation impact on soil erosion, Catena 83, 87-93, doi:10.1016/j.catena.2010.07.006, 2010.

Ziadat, F. M., and Taimeh, A. Y.: Effect of rainfall intensity, slope and land use and antecedent soil moisture on soil erosion in an arid environment, Land Degrad. Dev., 24, 582-590, doi:10.1002/ldr.2239, 2013. 